\title{
Bisnis Digital: Studi Kasus Penggunaan VTube, Jempol Preneur, dan Goins di Masa Pandemi Covid-19
}

\author{
Rifqiyani Nur Fadhillah \\ Universitas Hasanuddin \\ rifayaninf@gmail.com
}

\begin{abstract}
The Covid-19 pandemic has not only created social fear, but has also affected various aspects of human life, including in the field of economy. To reduce the spread of Covid19 , the government issued a work from home (WFH) policy and study from home. This not only limits the interaction between people, but this condition also causes people to be creative and look for alternatives to earn income. One that has the potential to be done is a digital business, which is not only easy and simple (using gadgets and internet networks), but can also be done anywhere, especially at home because of the "stay at home" policy, so that between looking for income and protecting oneself from spreading virus by staying at home is compatible with each other.
\end{abstract}

This study was conducted between September and December 2020 and is located in the city of Makassar. Makassar was chosen because digital business grew significantly. Based on data from the Central Statistics Agency (BPS), the economy in the Eastern part of Indonesia (KTI) grew by an average of $8 \%$, especially during the pandemic. There are seven participants who participated in this study who are varied based on age, occupation. Each informant is a user of one of the digital business platforms, namely VTube, Jempol Preneur, and Goins.

The study shows that digital business is one type of business by utilizing digital devices such as gadgets (mobile phones and laptops) and internet networks. Every digital business is now has a digital platform and has its own way of managing, as well as different advantages for its consumers. There are so many platforms that are engaged in digital business because it can be done easily, with a simple way of working, with the promise of a pretty lucrative income, and can be done anywhere. This fits perfectly with the Covid-19 pandemic situation where people stay at home. VTube, Jempol Preneur, and Goins are three applications that each have their own specifications and how they work. Vtube and Goins are digital platforms engaged in advertising, while Jempol Preneur is a platform digital business on online shop. Although there are similarities between the three, that is, making money even though each has its own variant. The income of VTube users depends on what users achieve by watching ads. In the application system of the Jempol Preneur, one must be a member to be able to run an online shop. As members, they not only choose the type and promote the goods that have been provided by the application, but this can also be run without capital (dropship), or with personal capital (reseller). Additional income can also be obtained through the sale of the Jempol Preneur license. The more licenses sold, the more income they can earned. Meanwhile, in Goins, users are supposed to carry out a mission by liking and watching advertising videos on the Instagram application. The more people who are 
invited to join, the more income is earned. However, despite the advantages that each application has, each has its drawbacks. If Jempol Preneur already has legality, then VTube and Goins are under construction, which shows that the legality of the two is not yet clear and this is related to the basis of the business being run. For this reason, users who have already run this business must be prepared to bear the risks, such as no return of money at all and the lack of clarity from the parties concerned. Another aspect that is considered a drawback of Jempol Preneur is the obligation to pay a registration fee while VTube and Goins do not require it.

Keywords: Covid-19, business digital, internet, application, platform and online.

\section{Pendahuluan}

Pada akhir tahun 2019, dunia digemparkan dengan munculnya virus baru di dunia dan berbahaya bagi umat manusia yaitu Severe Acute Respiratory Syndrome Coronavirus 2 (SARS-Cov-2) dan penyakit tersebut disebut Coronavirus Disease 2019, disingkat Covid-19. Virus ini menyerang sistem pernapasan manusia, seperti infeksi paru-paru dan dapat menyebabkan kematian. Ini menimbulkan ketakutan di masyarakat dan mereka berupaya untuk menghabiskan waktu lebih banyak di rumah. Virus yang berasal dari Wuhan (Cina), dan penyebaran virus berlangsung begitu cepat, hingga pada awal tahun 2020 virus tersebut masuk ke Indonesia dengan menularkan 2 orang WNI. Hanya membutuh waktu sekitar lima bulan (27 Juli 2020), tercatat ada 100.000 kasus Covid-19 di Indonesia. ${ }^{1}$

Masuknya Covid-19 di Indonesia mengharuskan pemerintah mengambil tindakan penanganan yang cepat. Menteri Kesehatan mengeluarkan Surat Edaran Nomor HK.02.01/Menkes/332/2020 Tahun 2020 tentang Penerapan Kebijakan untuk melaksanakan Pembatasan Sosial Berskala Besar (PSBB) sebagaimana tertuang dalam Peraturan Pemerintah Nomor 21 Tahun 2020 tentang

\footnotetext{
${ }^{1} \mathrm{https}$ //health.detik.com/berita-detikhealth/d5240992/perjalanan-8-bulan-pandemi-virus-coronacovid-19-di-indonesia, diakses tanggal 15 Februari 2021.
}

Pembatasan Sosial Berskala Besar Dalam Rangka Percepatan Penanganan Corona Virus Disease 2019 (Covid-19) dan Peraturan Menteri Kesehatan Nomor 9 Tahun 2020 tentang Pedoman Pembatasan Sosial Berskala Besar Dalam Rangka Percepatan Penanganan Corona Virus Disease 2019 (Covid-19). Dengan dikeluarkannya surat edaran ini, maka pemerintah menganjurkan agar semua aktivitas masyarakat dilakukan di dalam rumah, seperti proses belajar-mengajar dan bekerja dari rumah, dan sebisa mungkin untuk meminimalisir kegiatan di luar rumah.

Ini mengakibatkan banyaknya karyawan yang mengalami pemutusan hubungan kerja (PHK). Tercatat, pada tanggal 16 April 2020 pekerja yang berada di sector formal ada 229.789 orang mengalami pemutusan hubungan kerja. $^{2}$ Tidak hanya itu, para pengusaha pun menurunkan harga yang sangat drastis hingga tidak mengherankan banyak perusahaan yang "gulung tikar". Akibatnya, terjadi kemerosotan dalam dunia bisnis dan ekonomi (Fadly dan Sutama 2020).

Dengan kebijakan PSBB yang dicanangkan pemerintah, salah satu alternatif yang potensil dilakukan adalah dengan berbisnis online (online business) atau yang juga populer

2

https://www.kompas.com/tren/read/2020/04/19/0810 00465/total-19-juta-pekerja-di-phk-dan-dirumahkanakibat-pandemi-virus-corona?page $=$ all, diakses tanggal 23 Maret 2021. 
dikenal sebagai bisnis digital. Bisnis tersebut dapat dijalankan di mana saja dan kapan saja. Di masa pandemic Covid-19, ketika pemerintah mencanangkan untuk lebih banyak beraktivitas di rumah, bisnis ini menjadi alternative yang paling potensil dilakukan di dalam rumah tanpa harus keluar dan hanya bermodalkan gadget dan koneksi internet, penjualan dan pemasarannya pun dapat dilakukan dari rumah. Ini berkelindan dengan apa yang dikemukakan oleh Febriantoro dan Arisandi (2018), digital marketing memudahkan pelaku UMKM untuk memberikan informasi dan berinteraksi secara langsung secara digital dengan konsumen, memperluas pasar, dan meningkatkan penjualan.

Perkembangan teknologi saat ini sudah sangat pesat ke segala sisi kehidupan manusia yang kemudian dimanfaatkan oleh masyarakat untuk menunjang aktivitas sehari-hari. Dalam aspek ekonomi, misalnya, pemanfaatan perkembangan teknologi ini dimanfaatkan untuk memudahkan kegiatan bisnis ataupun membantu untuk memromosikan dan memasarkan barang dan jasa dalam bisnis tersebut. Dengan bantuan teknologi, maka bisnis yang dikelola akan sanagat membantu dan sangat potensil menghasilkan keuntungan bagi pemiliknya.

Hal inilah yang memicu munculnya $e$ Commerce, yaitu proses pembelian dan penjualan produk, jasa, dan informasi yang dilakukan secara elektronik dengan menggunakan jaringan komputer dan bantuan dari jaringan internet (Morissan 2010:336). Saat ini, e-Commerce memiliki tiga model bisnis yang cenderung diterapkan yaitu, B2B (Bisnis to Bisnis), B2C (Bisnis to Customer), C2C (Customer to Customer). Kini, perkembangan platfrom eCommerce di Indonesia kian pesat mengingat $e$ Commerce menjadi salah satu segmen bisnis digital yang telah terbukti tumbuh subur di
Indonesia. ${ }^{3}$ Salah satu contoh e-Commerce yang paling sederhana dan banyak digunakan di negara berkembang adalah iklan baris OLX, Berniaga, dan Tokobagus. Selain itu, ada Tokopedia dengan model bisnis C2C, Lazada, BerryBenka, dan Tiket.com dengan model bisnis B2C,

Tidak hanya istilah e-Commerce yang berkembang dalam dunia bisnis digital, ada istilah e-Business yang berbeda dengan $e$ Commerce. E-Business merujuk pada seluruh penggunaan tingkat lanjut dalam teknologi informasi dan komunikasi (TIK), khususnya teknologi jaringan dan komunikasi untuk meningkatkan cara organisasi melakukan seluruh proses bisnisnya mulai dari interaksi eksternal organisasi dengan para pemasok, pelanggan, investor, pemerintah, dan media massa. Tidak hanya itu, penggunaan teknologi informasi juga untuk mendesain kembali proses internalnya (Romney dan Steinbart 2006:58). Adapun contoh dari e-Business yaitu AirAsia.com, kaskus.us, dll.

Digital marketing merupakan upaya aktivitas pemasaran melalui media digital atau platform. Biasanya, media yang digunakan adalah melalui situs website, forum online, hingga yang paling popular adalah menggunakan media sosial, seperti Facebook, Instagram, Youtube, dll. (Sanjaya dan Tarigan 2009:47). Menurut Heidrick dan Struggless (2009:1), digital marketing merupakan perkembangan yang dilakukan melalui jaringan (web), telepon genggam dan perangkat games, menawarkan akses baru periklanan dan sangat berpengaruh bagi pengguna digital marketing. Dengan demikian, jika digital business merupakan salah satu jenis usaha yang memanfaatkan teknologi untuk menciptakan

\footnotetext{
${ }^{3}$ https://rakyatsulsel.co/2020/08/28/trenpemanfaatan-e-commerce-di-kalangan-umkm/, diakses tanggal 22 Februari 2021.
} 
produk maupun dalam pemasaran produk itu sendiri, digital marketing lebih terfokus pada pemanfaatan teknologi sebagai alat pemasarannya.

Di Indonesia, bisnis digital tidak diragukan lagi tingkat kesuksesannya dan kemajuannya dan Indonesia menjadi salah satu negara yang memiliki banyak pengguna internet dan gadget. Beberapa fakta lain yang mendukung perkembangan ekonomi digital di Indonesia, sebagaimana yang dijelaskan oleh McKinsey dan Company (2018:8) yaitu: (1) Indonesia diperkirakan memiliki pasar perdagangan online sebesar 5 miliar untuk perdagangan online formal, dan lebih dari tiga miliar untuk perdagangan online informal; (2) Indonesia diperkirakan memiliki 30 juta pembeli online pada tahun 2017 dengan total populasi sekitar 260 juta; (3) pada tahun 2025, ekonomi digital di Indonesia diperkirakan akan menciptakan 3.7 juta pekerjaan tambahan; (4) menghasilkan pertumbuhan pendapatan hingga $80 \%$ lebih tinggi untuk usaha kecil dan menegah (UKM); dan (5) memberikan tambahan 2\% per tahun dalam pertumbuhan PDB dengan meningkatkan tingkat penetrasi broadband dan penggunaan teknologi digital oleh UKM (Puslitbang Aptika dan IKP 2019:2).

Sebelum pandemi Covid-19, eksistensi bisnis digital adalah sesuatu yang nyata. Namun demikian, setelah Covid-19 mewabah, Sutrisni mengindikasikan tiga kondisi aktivitas bisnis digital: stabil, menurun, dan berkembang. Bisnis menjadi stabil karena bisnis tersebut melalui penyesuaian model interaksi dalam penggunaan aplikasi online (seperti sektor pendidikan, makanan/minuman, kebutuhan pokok, dan produk kesehatan. Bisnis menjadi menurun pada bisnis berbasis kunjungan (seperti angkutan umum, pariwisata, perhotelan, ritel offline, pusat perbelanjaan, angkutan orang dan barang). Bisnis berkembang karena dinamika pasar dan penyesuaian interaksi menggunakan platform aplikasi online (seperti bisnis telekomunikasi, belanja online untuk kebutuhan pokok dan produk kesehatan), farmasi, produk kesehatan, termasuk UMKM yang beralih secara inovatif memproduksi produk kesehatan yang dibutuhkan di masa pandemi Covid- 19 (Sutrisni 2020). Ini menunjukkan bahwa meskipun bisnis digital telah ada sebelum pandemi, penyesuaian selama masa pandemi tetap diperlukan. Ini berkelindan dengan temuan Hapsoro (2019) terkait usaha mikro, kecil, dan menengah yang mengindikasikan bahwa di tengah perkembangan teknologi yang begitu pesat, UMKM harus mampu berbenah dan melakukan inovasi melalui digital marketing, dan tidak sekedar untuk bertahan, tetapi juga mampu menikmati keuntungan finansial dari perubahan tersebut. Demi bertahan di masa pandemi Covid-19, temuan Rosmadi (2021) menunjukkan bahwa pelaku UMKM kuliner menggunakan dua strategi utama dalam bisnis digital, yakni penggunaan media sosial untuk memromosikan produk bisnis dan penetapan harga yang sesuai dengan daya beli masyarakat.

Diskusi dalam artikel ini akan dibagi atas tiga bagian. Bagian pertama akan membahas tentang persepsi pengguna bisnis digital dalam kaitan dengan digital marketing. Ini diikuti dengan pembahasan tentang cara kerja bisnis digital. Pada bagian akhir, pembahasan difokuskan pada kelebihan dan kekurangan dalam penggunaan bisnis digital.

\section{Metode Penelitian}

Penelitian ini dilaksanakan antara bulan September dan Desember 2020 dan berlokasi di kota Makassar. Lokasi ini dipilih dengan pertimbangan pertumbuhan bisnis digital cukup signifikan, berdasarkan data Badan Pusat Statistik (BPS), perekonomian daerah di timur Indonesia mampu bertumbuh dengan rata-rata 
7-8\%. Terutama di masa pendemi ketika pemerintah mencanangkan work from home (WFH, bekerja dari rumah) dan meminimalisir kegiatan di luar rumah.

Adapun teknik pengumpulan data dilakukan melalui wawancara mendalam (indepth interview) dan observasi (observation). Wawancara mendalam dilakukan untuk mengetahui mengenai persepsi informan tentang bisinis digital, cara kerja, kelebihan, serta kekurangan dalam menggunakan bisnis digital selama masa pendemi Covid-19.

Oleh karena pemerintah mencanangkan untuk berkegiatan di dalam rumah, maka wawancara dilakukan secara online dengan memanfaatkan platfrom yang ada seperti Whatsapp, Instagram, dan Facebook. Metode ini diistilahkan oleh Schimier (dalam Ismail dkk. 2019) metode connective ethnografi yang memungkinkan untuk melakukan wawancara secara online, tanpa harus face to face atau berinteraksi secara fisik. Wawancara dilakukan melalui aplikasi Whatsapp. Sementara, teknik observasi dilakukan untuk mengamati platfrom yang menjadi wadah untuk menjalankan bisnis digital dengan cara mengunduh salah satu platform tersebut.

Informan dalam penelitian ini berjumlah tujuh tujuh orang yang bervariasi berdasarkan usia (antara 20 dan 35 tahun), pekerjaan (empat orang mahasiswa, satu orang karyawan swasta, satu orang wirausaha, satu orang guru mengaji. Masing-masing informan merupakan pengguna salah satu platform bisnis digital, yaitu VTube, Jempol Preneur, dan Goins.

Analisis data dilakukan dengan mengumpulkan semua data yang diperoleh selama di lapangan, baik itu transkrip catatan wawancara maupun observasi. Data ini kemudian dikelompokkan berdasarkan tema yang muncul, yakni bisnis digital dan jenis bisnis digital yang digunakan informan, sistem kerja, kelebihan dan kekurangan bisnis digital.

Dalam penelitian ini, kesediaan informan diminta melalui chat personal pada aplikasi Whatsapp dengan menjelaskan identitas, maksud dan tujuan berkomunikasi. Jika mereka setuju untuk melanjutkan, maka saya menjelaskan penelitian yang akan dilakukan (topik, tujuan, dan manfaat). Jika mereka setuju untuk berpartisipasi, maka mereka dimintai kesediaan untuk diwawancarai melalui telfon, voice note, dan meminta salah satu fotonya, serta menyimpan screenshot roomchat di Whatsapp. Atas kesepakatan bersama, semua komunikasi dilakukan secara digital tanpa interaksi fisik mengingat bahwa Covid-19 masih mewabah. Identitas informan dijaga kerahasiaannya dan diproteksi melalui penggunaan nama samaran, sebagaimana yang diinginkan oleh informan yang berpartisipasi dalam penelitian ini.

\section{Bisnis Digital}

Dunia bisnis sudah tidak asing lagi untuk didengar dan dibicarakan. Di zaman seperti ini, sudah banyak manusia merintis usaha sendiri atau membangun bisnis sendiri dan tidak lagi bekerja di bawah tekanan, sebagai pegawai atau karyawan. Salah satu alasan ingin memiliki bisnis sendiri, yaitu keuntungan sepenuhnya milik pribadi, jika ia tidak merekrut karyawan. Selain itu, seseorang dapat mengatur dan mengelola segala sesuatu yang berhubungan dengan perusahaan atau bisnis yang dikelolanya, seperti keuangan, barang dan jasa. Pada awalnya, dunia bisnis melakukan proses transaksi-pertukaran barang dan jasa-melalui face to face atau ketemu secara langsung. Proses tersebut terjadi ketika adanya kesepakatan antar dua pihak, biasanya pertukaran tersebut tidak selalu dalam bentuk pecahan uang, akan tetapi bisa dalam bentuk 
barang. Menurut Skinner (1992:45), bisnis adalah pertukaran barang, jasa, atau uang yang saling menguntungkan atau memberikan manfaat, sedangkan menurut asli dasarnya bisnis memiliki makna sebagai the buying and selling of goods and services (membeli dan menjual barang dan jasa). Dengan adanya perkembangan teknologi, maka dunia bisnis pun ikut dalam perkembangan tersebut. Kemudian, dunia bisnis menjadi begitu cepat berkembang dengan banyaknya bermunculan orang-orang yang kreatif dan inovatif, sehingga dalam dunia tersebut persaingan sangat tinggi.

Kemunculan teknologi digital dan internet dimulai pada revolusi industri 3.0. Sebelumnya, pada era 2.0, teknologi yang hadir adalah teknologi mesin yang dapat menciptakan sebuah kendaraan (mobil) dan membuat waktu dan jarak semakin dekat. Ketika masuk di era 3.0, kehadiran teknologi digital dan internet membuat orang ingin memilikinya, selain karena sedang tren, ini juga dapat memudahkan orang beraktifitas. Hadirnya teknologi digital dan internet membuat komunikasi semakin lancar dan canggih, tidak lagi harus menunggu waktu yang sangat lama untuk saling membalas pesan dan berkabar sapa. Selain itu, pengguna digital dan teknologi pun dapat dengan leluasa mengakses berbagai informasi yang diinginkan sesuai kebutuhan (Nugraha dan Murniawaty 2020:241-252).

Setelah Revolusi Industri 3.0 kini kita berada pada era Revolusi Industri 4.0. Banyak inovasi baru yang tidak pernah ada di era Revolusi Industri 3.0, antara lain Internet of Things (IoT), Big Data, percetakan 3D, Artifical Intelligence (Al), kendaraan tanpa pengemudi, rekayasa genetika, robot dan mesin pintar. Salah satu inovasi terbesar dalam Revolusi Industri 4.0 adalah loT. IoT memiliki kemampuan dalam menyambungkan dan memudahkan proses komunikasi antara mesin, perangkat, sensor, dan manusia melalui jaringan internet. Misalnya, jika di era Revolusi Industri 4.0 transfer uang hanya dapat dilakukan melalui ATM atau teller bank, maka kini transfer uang dapat dilakukan dimana saja dan kapan saja selama seseorang terhubung dengan jaringan internet melalui aplikasi yang ada di dalam gadget kita. Aktifitas keuangan juga dapat dikontrol dimanapun dan kapanpun melalui aplikasi yang ditunjang oleh jaringan internet. ${ }^{4}$

Dalam kaitan dengan bisnis digital, teknologi digital memungkinkan orang untuk mengendalikan bisnisnya dimana dan kapan saja melalui bantuan jaringan internet dengan menggunakan perangkat, seperti gadget. Ini terutama karena penggunaan e-mail, website, platform online, serta bertransaksi secara online telah menjadi bagian dari kehidupan sehari-hari. Dengan demikian, menurut Maryati dan Masriani (2019), teknologi digital memang membuka peluang besar untuk berwirausaha. Ini mengindikasikan bahwa bisnis digital memberikan kemudahan dalam mengelola bisnis bagi para penggunanya, terlebih di masa pandemi Covid-19, sehingga tidak sedikit masyarakat yang membuka bisnis digital. Tidak hanya itu, platform online yang dapat menghasilkan uangpun mulai bermunculan satu per satu dan cukup banyak orang yang menggunakannya.

Menurut Hamzah (20 Tahun), bisnis digital merupakan bisnis yang memanfaatkan dan menggunakan gadget, seperti handphone dengan bantuan dari jaringan internet. Bisnis tersebut dapat menghasilkan uang hanya dengan cara bermain handphone. Sementara, menurut Lola (22 tahun) bisnis digital merupakan bisnis yang memanfaatkan

\footnotetext{
${ }^{4}$ https://binus.ac.id/knowledge/2019/05/mengenallebih-jauh-revolusi-industri-4-0/, diakses tanggal 15 Juni 2021.
} 
perangkat digital seperti handphone, laptop, dan berbagai alat teknologi lainnya.

Setiap platform bisnis yang hadir mempunyai cara kerja tersendiri dan keunggulan yang berbeda-beda untuk memikat konsumennya. Ada beberapa contoh platform online yang khusus bergerak dalam dunia bisnis, yaitu Go-Jek, Grab, dan Maxim (untuk transportasi), OVO, Dana, dan lainnya (untuk $e$ wallet), Buka Lapak, Shopee, Lazada, Blibli, dan lainnya untuk e-commerce.

Bisnis digital yang sedang peopuler adalah VTube. VTube merupakan salah satu platform yang bergerak di bidang periklanan dan orang akan mendapatkan uang atau penghasilan hanya dengan menonton video iklan. ${ }^{5}$ Penghasilan yang diperoleh dari VTube pun tidak terbatas karena, selain mendapatkan uang dengan menonton iklan, pengguna platform ini juga dapat menghasilkan uang dengan cara merekrut anggota atau melalui kode referral code yang digunakan untuk mengundang orang menggunakan VTube. Menurut Joe (20 tahun), VTube merupakan salah satu bisnis digital yang bergerak dalam bidang periklanan dengan sistem bagi hasil antara pemilik iklan dan penonton iklan. Sementara, menurut Andi (35 Tahun), VTube merupakan salah satu aplikasi atau platform yang dapat menghasilkan uang hanya dengan menonton iklan sesuai dengan aturan yang ada, sistem yang digunakan hampir sama dengan MLM (Multi Level Marketing), yakni semakin banyak member atau perekrutan anggota yang diperoleh, maka semakin banyak pula bonus atau profit yang dihasilkan. Namun, dalam aplikasi VTube tidak harus merekrut anggota untuk mendapatkan penghasilan, melainkan jika bekerja sendiri tetap akan mendapatkan hasil.

\footnotetext{
${ }^{5}$ https://www.tahukau.com/, diakses tanggal 1 Juni 2021 .
}

Oleh karenanya, berlomba-lomba untuk menggunakan platform tersebut. Bahkan beberapa perusahaan telah memasukkan produk-produknya ke dalam platform tersebut agar lebih banyak lagi yang mengetahui dan mengenal produknya. Adapun produk-produk yang telah masuk dan beriklan di VTube, yaitu Mcdonald, Sturbucks, Pepsodent, dan barangbarang branded lainnya.

Platform tersebut telah mendapatkan izin dari pemerintah untuk mengelola dan mengembangkannya. Dengan demikian, pengguna tidak perlu lagi merasa khawatir akan tipuan terkait platform tersebut. Namun, ini bukan berarti semua platform telah melewati prosedur-prosedur yang ada dan telah medapatkan persetujuan dari pemerintah. Tidak sedikit platform yang seperti itu menyebar luas ke masyarakat dengan janji akan mendapatkan uang dengan mudah dan cepat, sehingga orang ikut bergabung dalam platform tersebut tanpa mencari tahu terlebih dahulu kebenarannya, salah satunya adalah Goins. Menurut Lola (20 tahun), Goins merupakan bisnis digital atau aplikasi dengan cara menonton iklan yang ada di Instagram. Namun, aplikasi tersebut belum diketahui legalitasnya, sehingga mengharuskan pengguna untuk berhati-hati menggunakannya.

Ada pula platform Jempol Preneur. Menurut Ina (20 tahun), aplikasi Jempol Preneur merupakan aplikasi yang menjadi wadah untuk bisa membuka usaha online (online shop) yang terlebih dahulu harus melakukan registrasi untuk bergabung dalam aplikasi tersebut. Selain itu, aplikasi tersebut dapat mengundang orang atau merekrut anggota dan semakin banyak anggota yang direkrut, maka akan semakin banyak pendapatan yang diperoleh. Aturan ini hampir sama dengan yang berlaku pada MLM, namun pengguna aplikasi ini juga dapat bermain sendiri tanpa merekrut anggota. 
Ketiga aplikasi di atas sangat berguna dan bermanfaat bagi para penggunanya, terutama di masa pendemi Covid-19 yang mengharuskan masyarakat untuk tetap tinggal di rumah demi memutus mata rantai perkembangan virus Covid-19. Menurut Andjo (22 tahun), dengan adanya aplikasi tersebut, pengguna dapat menghasilkan uang hanya dengan bermain handphone dan bermodalkan kuota internet tanpa harus keluar rumah, serta menjadi pekerjaan sampingan untuk mencukupi kebutuhan ekonomi.

\section{Cara Kerja Bisnis Digital}

Untuk memulai pemasaran suatu bisnis dengan sistem digital, maka dibutuhkan beberapa keterampilan khusus, seperti strategi pemasaran, mengoptimalkan konten marketing, mengetahui dan memahami cara kerja bisnis digital. Secara umum, bisnis digital dapat bekerja secara organic (tidak berbayar) atau paid marketing (berbayar). Selain itu, cara kerja bisnis digital cukup bervariasi, namun sebenarnya mempunyai tujuan yang serupa, yaitu meningkatkan penjualan, mendapatkan keuntungan, serta yang paling penting menarik hati para konsumen. Hal yang harus dimiliki oleh sebuah bisnis di dunia digital yaitu website sebuah halaman yang berada di internet dan dapat diakses oleh semua pengguna internet karena hal inilah yang akan dipromosikan melalui bisnis digital.

Adapun cara kerja bisnis digital yang sangat umum dilakukan oleh pemilik bisnis digital yaitu (1) membangun sebuah website atau akun marketplace untuk bisnis yang akan dipromosikan; (2) membuat postingan di website atau akun marketplace tersebut, (3) memilih media periklanan digital marketing, (4) melakukan analisis pasar, (5) membuat iklan yang menarik dengan menautkan post website atau marketplace, (6) Publikasi iklan, dan (7) menghasilkan pelanggan dari iklan tersebut. ${ }^{6}$ Namun, beberapa bisnis digital memiliki cara kerja tersendiri untuk meningkatkan penjualan dan menguntungkan pengguna bisnis digital. Tiga platform bisnis digital yang digunakan oleh informan yang berpartisipasi dalam penelitian adalah VTube, Jempol Preneur, dan Goins.

\section{VTube}

VTube merupakan salah satu platform yang bergerak dalam bidang periklanan dan lauching pada bulan April 2020 yang artinya sudah dapat diakses dan diunduh secara bebas dan gratis melalui Google Playstore (Android) yang sebelumnya VTube hanya dapat diakses dan diunduh melalui link yang disebarkan melalui media sosial (lihat Gambar 1). Namun, pada saat itu pengguna iOS (Apple) belum dapat mengaksesnya. Setelah melewati proses launching, VTube masih selalu melakukan pembahuruan dan selalu mengalami perbaikan. Menurut Joe (20 tahun), ini karena masih banyaknya kekurangan yang terdapat pada VTube. Selain itu, masih banyak prosedurprosedur yang belum terpenuhi seperti surat izin dari Kominfo, surat izin dari PSE (penyelenggara sistem elektronik), dll., sehingga legalitas VTube masih dipertanyakan.

\footnotetext{
${ }^{6}$ https://www.advernesia.com/blog/digitalmarketing/konsep-dan-cara-kerja-digital-marketingterhadap-bisnis-online/, diakses tanggal 15 Mei 2021.
} 

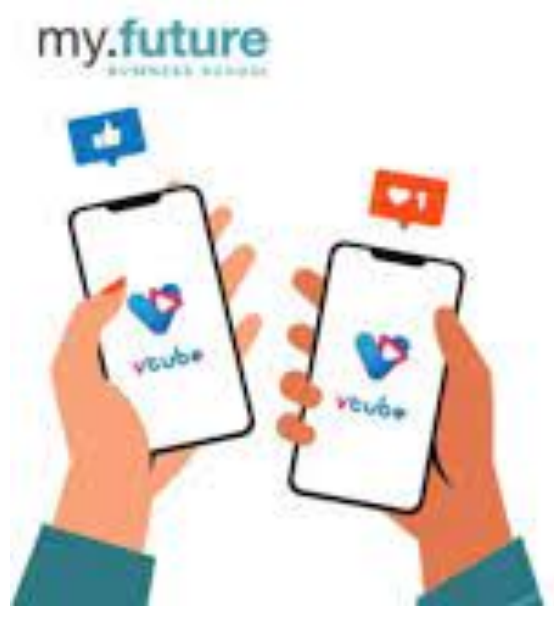

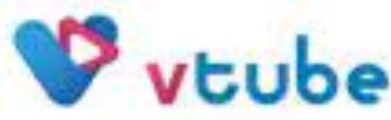

"Ubah hiburan

jadi penghasillan"

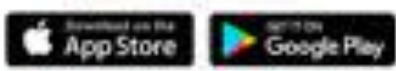

$100 \%$ GRATIS

TANPA MODAL

perusahasen tidak boleh menerima

uang sepeserpun darl Anggora

Gambar 1. VTube

Setelah pengguna telah mengunduh aplikasi VTube, maka pengguna harus melakukan registrasi dengan mengisi data pribadi yang telah dicantumkan pada aplikasi VTube. Pengguna juga harus memiliki Telegram untuk mendapatkan kode OTP dari VTube. Setelah pengguna berhasil menunduh platform tersebut, maka pengguna harus melakukan proses registrasi pada platform tersebut, yaitu mengisi nomor telfon, new password, mengonfirmasi new password, OTP (untuk mendapatkannya, pengguna diarahkan untuk mengklik request OTP yang ada pada kolom di VTube. Kemudian pengguna akan mendapatkan pesan di Telegram yang berisikan kode OTP). Ini dilanjutkan dengan mengisi kode capcha, mengklik term and condition, dan mengklik submit. Selain itu, pengguna VTube juga diminta untuk memasukkan nomor KTP (kartu tanda penduduk) dan nomor KK (kartu keluarga), dalam proses registrasi pengguna sama sekali tidak dipungut biaya. Setelah melakukan registrasi awal, maka pengguna diminta untuk memasukkan kode referral dari seseorang yang telah menjadi member VTube sebelumnya, seperti kenalan, teman, atau kerabat yang menggunakan VTube. Selanjutnya, pengguna harus menunggu $1 \times 24$ jam untuk proses konfirmasi dari pihak VTube agar dapat mengoperasikan VTube dan menjadi member atau anggota.

Ketika pengguna VTube telah berhasil menjadi salah satu bagian dari member atau anggota VTube, maka hal pertama yang harus dilakukan yaitu menjalan sebuah misi dari VTube. Misi inilah yang jika dikerjakan dan diselesaikan sesuai waktu yang ditargetkan akan mendapatkan penghasilan. Misi tersebut, yaitu menonton video iklan sebanyak sepuluh kali dengan durasi jarak antara video pertama, kedua, dan seterusnya adalah sepuluh menit. Tidak semua iklan yang ada di VTube harus dinonton, melainkan iklan yang bertuliskan "Ads" jika menonton iklan. Selain dari iklan yang telah ditentukan, ini tidak akan terhitung dan dinyatakan "belum menonton iklan". Misi ini dijalankan selama 40 hari, dan harus dilakukan setiap hari dengan cara yang sama dan konsisten. Setiap satu video atau satu iklan yang dinonton akan mendapatkan 0,3 VP (view point) atau setara dengan 0.3 dollar. Inilah yang ditargetkan oleh para pengguna VTube, dalam mengumpulkan VP (view point) sebanyakbanyaknya dan akan ditukarkan dengan uang 
atau VP tersebut diperjual belikan kepada sesama pengguna VP sesuai dengan harga yang berlaku, yaitu 1 VP setara dengan 1 dollar. Setelah melakukan misi pertama, maka akan dilanjutkan dengan misi kedua begitupun selanjutnya. Misi yang dijalankan masih sama seperti misi sebelumnya, yang membedakan hanyalah pendapatan VP. Semakin tinggi tingkatan level yang dijalankan, maka semakin banyak pula VP yang didapatkan. Cara kerja seperti ini adalah cara kerja solo atau sendiri, artinya ia tidak merekrut member atau menyebarkan kode referral yang dimilikinya. Namun cara kerja seperti ini memakan waktu yang cukup lama untuk mendapatkan penghasilan yang banyak. Selain itu, jika dikaitkan dengan UU No. 7 tahun 2011 tentang Mata Uang, VTube dianggap melanggar UU tersebut karena dalam operasi kegiatan referral, VTube menggunakan mata uang dollar ketimbang rupiah. ${ }^{7}$

Untuk penghasilan yang maksimal, anggota VTube berlomba-lomba mengajak orang-orang di sekelilingnya (kenalan, teman, kerabat, saudara, bahkan keluarga) untuk bergabung menggunakan VTube. Jika ia berhasil, dan pengguna baru menggunakan kode referralnya, maka ia akan mendapatkan tambahan VP. Semakin banyak anggota yang dapat ia rekrut, maka semakin banyak pula VP yang diperoleh. Segala cara dilakukan untuk mencari atau merekrut member, mulai dari memosting di media sosial, seperti Facebook, Instagram, Twitter; menyebarluaskan info melalui grup-grup yang ada di Whatsapp atau Telegram terkait keuntungan memakai VTube; membuat banner atau stan-stan di pinggir jalan untuk memromosikan VTube sekaligus membantu new member untuk bergabung di

${ }^{7}$ https://prfmnews.pikiran-rakyat.com/cek-fakta/pr131397205/benar-atau-hoaks-aplikasi-vtube-ilegal-diindonesia?page $=2$, diakses tanggal
VTube. Semakin banyak member yang direkrut, semakin banyak bonus yang diperoleh. Ini terkait dengan peringkat-peringkat yang ada di VTube. Ketika salah seorang member berhasil mengumpulkan 20 new member, maka ia akan mendapatkan bonus VP dari VTube. Selain itu, ia akan mendapatkan peringkat atau rank, yaitu dari yang paling rendah (bronze) hingga peringkat yang paling tinggi (diamond) dalam VTube. ${ }^{8}$

Semakin banyak new member yang direkrut, maka ini juga akan membuat semakin tinggi rank yang diperoleh. Rank merupakan tingkat setiap pengguna dalam merekrut anggota atau new member untuk memakai VTube. Semakin banyak anggota yang diperoleh, maka akan semakin meningkat pula level yang diperoleh. Setiap peringkat memiliki bonus yang berbeda-beda dan cara kerja yang berbedabeda.

Namun sebelumnya, pengguna VTube harus memastikan terlebih dahulu bahwa aplikasi VTube yang digunakan merupakan versi terbaru. Jika VTube yang digunakan bukan versi terbaru, maka ia harus memperbaharui terlebih dahulu di Playstore atau melalui link yang tersedia.

Terlepas dari berbagai aktifitas yang harus dilakukan, biasanya jika ada yang mengajak untuk ikut menjadi anggota dari aplikasi ini, dengan tagline "nonton iklan, dapat uang", simpel tapi menggiurkan. Di masa pandemi Covid-19, ketika situasi sedang krisis, ajakan seperti itu bagai sebuah cahaya dalam kegelapan, sehingga banyak orang yang tertarik untuk mengikutinya, bahkan seringkali tanpa melihat rekam jejaknya terlebih dahulu, apalagi mempertanyakan legalitasnya.

\footnotetext{
${ }^{8}$ Rank atau peringkat dalam VTube dari yang terendah ke yang tertinggi secara berturut-turut adalah bronze silver, gold, platinum, dan diamond.
} 


\section{Jempol Preneur}

Jempol Preneur merupakan sebuah komunitas belajar bisnis online yang juga dapat menghasilkan uang melalui internet (lihat Gambar 2). Komunitas ini belum terkenal seperti halnya bisnis-bisnis yang lainnya dikarenakan bisnis ini baru dirilis pada tanggal 21 April 2020. Hal yang menarik dari komunitas ini, yaitu keanggotannya disatukan dalam sebuah aplikasi dari Jempol Preneur, dan dalam aplikasi tersebut sudah lengkap suatu bacaan yang berisikan cara memulai bisnis online bagi pemula. Selain itu, istilah-istilah bisnis di dalam aplikasi tersebut juga dijelaskan, dengan tujuan agar para pengguna tidak lagi salah atau keliru dalam menjalankan bisnis online, terutama bagi pemula. Aplikasi ini dapat di temukan di Playstore (bagi pengguna Android) dan Appstore (bagi pengguna IPhone), sebagaimana yang dikatakan oleh Harza (21 tahun), bahwa aplikasi ini memberikan banyak pengetahuan dan panduan untuk membuka usaha atau bisnis online, serta telah disediakan beraneka ragam barang yang dapat diperjual-belikan.

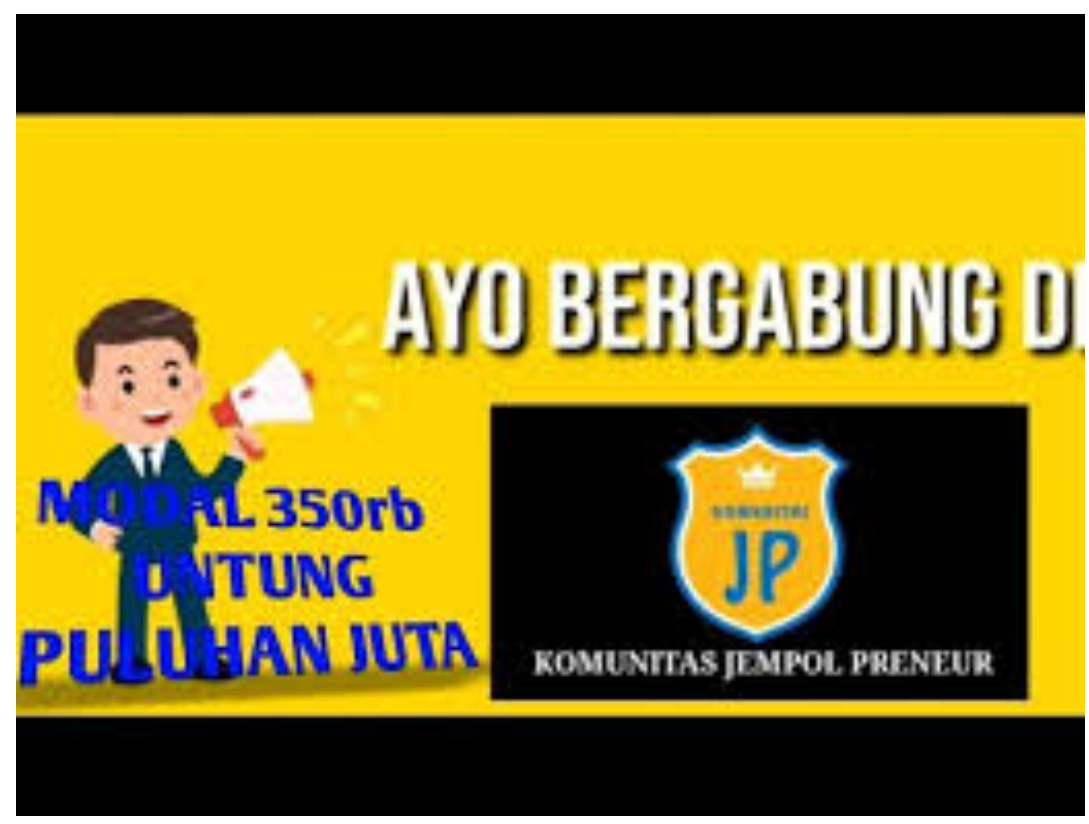

Gambar 2. Jempol Preneur

Untuk menjadi bagian dari anggota Jempol Preneur, anggota harus terlebih dahulu mengunduh aplikasi Jempol Preneur dan Telegram. Setelah mengunduh aplikasinya, maka anggota akan diarahkan untuk mengisi data diri yang telah sediakan atau registrasi. Sama halnya dengan VTube, aplikasi ini juga membutuhkan kode referral yang akan digunakan untuk menjadi bagian dari anggota tersebut. Kode referral diperoleh dari anggota Jempol Preneur yang telah bergabung, seperti kenalan, teman, kerabat, saudara, atau keluarga. Namun, berbeda dengan VTube, aplikasi ini memungut biaya pendaftaran sebesar Rp350.000 dan dikirimkan kepada nomor rekening yang telah tersedia pada aplikasi. Uang yang telah dikirim, secara otomatis akan dibagikan kepada dua pihak, pihak pertama sebagai pemilik nomor rekening yang tercantum dalam aplikasi akan mendapatkan Rp100.000, sedangkan sisanya (Rp.250.000) akan masuk ke dalam akun 
pengguna Jempol Preneur yang kode referralnya telah digunakan. Uang tersebut dapat diambil dengan cara mencairkannya melalui aplikasi tersebut dan otomatis akan masuk ke dalam nomor rekening pengguna yang telah dicantumkan di dalam aplikasi.

Selain mengunduh aplikasi Jempol Preneur, pengguna juga diwajibkan untuk mengunduh aplikasi Telegram. Adapun aplikasi Telegram ini digunakan untuk bergabung dalam group chat yang berisikan semua anggota Jempol Preneur. Grup tersebut akan memudahkan para anggota untuk mengetahui info terbaru mengenai aplikasi Jempol Preneur, seperti info pembahuruan aplikasi, dll. Serta, anggota dapat bertanya dalam grup tersebut jika ada hal yang perlu dipertanyakan atau kurang dipahami dalam penggunaan aplikasi tersebut. Jika anggota merasa kurang cukup mendapatkan info melalui group chat, maka anggota dengan bebas mengunjungi website Jempol Preneur, yaitu yang berisikan kumpulan artikel tentang bisnis.

Platform inipun telah bekerja sama dengan beberapa marketplace atau e-Bussines lain (seperti Instagram dan Shopee). Ketika seorang member baru telah bergabung, maka ia akan mendapatkan panduan membuka onlineshop tanpa modal (dropship) atau dengan menggunakan modal (reseller). Semua pilihan atau jenis penjualan telah disediakan dalam platform tersebut seperti assesoris, fashion, makanan, minuman, dll. Ketika pengguna telah memilih satu di antaranya, maka secara otomatis platform tersebut mengarahkan pengguna mengambil barang atau produk di Instagram atau Shopee. Penggunapun tidak perlu lagi mencari akun-akun Instagram atau Shopee yang dipercaya dan mempunyai banyak pilihan, karena platform tersebut telah menyediakannya, bahkan langsung diarahkan ke akun tersebut. Setelah anggota mendapatkan barang yang dicari, maka anggota dapat mengambil gambarnya dan mempromosikannya untuk dijual melalui akun media sosial yang dimiliki seperti Whatsapp, Telegram, Instagram, Facebook, Twitter, dll. dimana pengguna telah menaruh harga pada barang yang dipilih. Dari sinilah pengguna atau anggota mendapatkan keuntungan. Semakin rajin pengguna mencari barang dan mempromosikan barang tersebut, maka akan semakin banyak pula keuntungan yang diperoleh.

Selain menggunakan cara tersebut, pengguna juga dapat menghasilkan uang dengan cara menjual lisensi Jempol Preneur. Lisensi yang dimaksud yaitu, menjual kode atau link Jempol Preneur yang dimiliki setiap anggota. Jika anggota berhasil menjual link tersebut, maka anggota akan mendapatkan bonus atau fee sebesar Rp250.000,-. Ketika anggota berhasil menjual banyak link ke orang yang dikenalnya (seperti kenalan, teman, saudara, keluarga, atau kerabat), maka semakin banyak pula keuntungan yang diperoleh. Di masa pandemi Covid-19, ini menjadi sangat berarti untuk mengisi pundi-pundi yang krisis akibat wabah tersebut.

Oleh karenanya, banyak anggota Jempol Preneur yang berlomba-lomba menjual dan mempromosikan link atau kode tersebut dengan beragam cara, seperti memberikan edukasi kepada kenalannya tentang Jempol Preneur, memublikasikan info dan keuntungan serta testimoni menggunakan Jempol Preneur melalui akun media sosial yang mereka miliki, seperti Whatsapp, Telegram, Instagram, Facebook, Twitter, Line, dll. seperti yang dilakukan Ina (21 tahun). Tidak hanya itu mereka juga melakukan perbincangan face to face tentang apa saja yang terkait dengan Jempol Preneur. 
Goins

Goins merupakan salah satu aplikasi bisnis digital yang dapat menghasilkan uang dengan cara yang cukup mudah (lihat Gambar 3). Di masa pandemi Covid-19, ini sangat menggiurkan karena orang berupaya mengimbangi krisis yang terjadi dengan mencari penghasilan tambahan atau bahkan penghasilan utama. Kemudahan ini yang menarik banyak orang untuk bergabung.

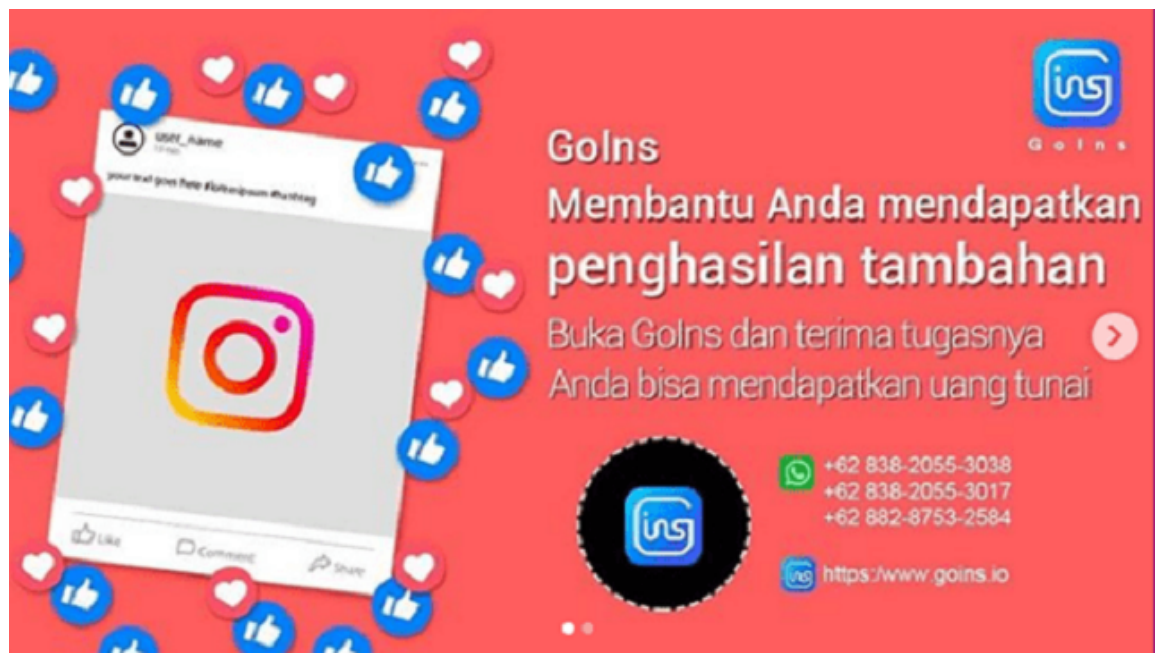

Gambar 3. Goins

Aplikasi ini lahir pada saat pandemi Covid-19 di tahun 2020, sehingga masih relatif baru dan belum banyak diketahui orang karena aplikasi ini juga belum terdaftar di Playstore dan Appstore. Namun, orang dapat mengunduh aplikasi tersebut melalui link yang telah diperoleh dari kenalan, teman, keluarga, saudara, atau kerabat. Menurut Lola (22 tahun), pengguna aplikasi Goins, ia belum mendapatkan informasi tentang perizinan aplikasi Goins dari pihak Kominfo atau OJK. Namun, Lola tetap menggunakan aplikasi tersebut karena ia direkomendasikan oleh saudaranya serta telah melihat hasil yang diperolehnya. Dalam kasus Lola, meskipun ia mempertanyakan legalitas dari aplikasi Goins, ia tetap menggunakannya atas rekomendasi saudaranya. Artinya, rekomendasi dari seseorang yang telah mendapatkan keuntungan dari penggunaan aplikasi ini berperan signifikan untuk memengaruhi orang lain ikut menjadi pengguna aplikasi ini, apalagi jika yang merekomendasikan adalah anggota keluarganya sendiri.
Bagaimana proses untuk menjadi anggota? Setelah mengunduh aplikasi Goins, maka pengguna akan melalukan proses pendaftaran yang telah disediakan dalam aplikasi Goins. Adapun cara mendaftar untuk membuat akun dan mendapatkan penghasilan dari aplikasi Goins tidak jauh berbeda dengan aplikasi yang telah dijelaskan sebelumnya, mulai dari mengisi data diri atau identitas lengkap seperti nama, e-mail, nomor telfon, password, dan kode undangan. Kode undangan diperoleh dari pengguna Goins yang telah lama bergabung, atau dari kenalan yang mengundang untuk menggunakan Goins. Setelah proses pendaftaran selesai, maka pengguna harus login pada aplikasi Goins untuk mendapatkan penghasilan.

Selanjutnya, pengguna menjalankan misi dari aplikasi Goins untuk mendapatkan penghasilan. Misi yang terdapat dalam aplikasi Goins pun berbeda-beda, sesuai dengan level yang diinginkan. Namun, ketika ingin menjalankan sebuah misi, pengguna akan 
dikenakan biaya membeli misi atau menanam modal. Lola (22 tahun), misalnya, memilih misi pada level tingkat tiga, maka ia harus membayar senilai Rp2.000.000 untuk menjalan misi tersebut dan misi tersebut berlaku selama satu tahun.

Adapun misi yang dijalankan, yaitu dengan memberikan like pada foto atau menonton video iklan yang berada pada aplikasi Instagram. Adapun foto yang harus di-like sebanyak 30 foto dalam sehari tanpa adanya jarak durasi waktu antara foto satu dan foto selanjutnya. Ketika ingin menjalankan misi tersebut, maka pengguna akan diarahkan melalui link yang telah disediakan dalam aplikasi Goins. Jika pengguna telah mengklik link tersebut, maka secara otomatis akan terbuka aplikasi Instagram serta foto apa saja yang harus di-like dan video apa saja yang harus dinonton. Menurut Lola (22 tahun), kebanyakan foto yang ia like atau video yang ia tonton adalah foto atau video yang berasal dari luar negeri, barangbarang yang terkenal dan bermerek (branded), serta para selebgram. Setelah Lola berhasil menjalankan misi selama sebulan, ia mendapatkan keuntungan sebanyak Rp700.000,- dan dapat dicairkan melalui rekeningnya.

Selain itu, ia dapat memeroleh penghasilan tambahan dengan mengundang orang sebanyak-banyaknya untuk bergabung dan menggunakan aplikasi Goins. Serupa dengan aplikasi VTube dan Jempol Preneur, semakin banyak anggota atau member yang direkrut untuk menggunakan Goins, maka akan semakin banyak pula bonus yang diperoleh. Oleh karenanya, banyak yang berlomba-lomba untuk memberikan informasi kepada siapa saja, seperti kenalan, teman, saudara, keluarga, dll. tentang aplikasi ini, serta menginformasikan keuntungan yang diperoleh jika menggunakan aplikasi tersebut.

\section{Kelebihan dan Kekurangan Bisnis Digital}

Setiap platform atau aplikasi bisnis digital tentunya memiliki kelebihan dan kekurangan di dalamnya. Oleh karena itu, sebagai pengguna bisnis digital, seseorang harus dapat memahami dan dapat memilah mana yang memiliki kelebihan dan lebih menguntungkan. Jika pengguna tidak cerdas dalam memilah, maka akan terjadi sesuatu yang tidak diinginkan atau kerugian yang besar bagi pengguna aplikasi bisnis digital, di satu sisi. Ketika banyak masyarakat yang terdampak PHK (pemutusan hubungan kerja) dan adanya aturan dari pemerintah untuk meminimalisir kegiatan di luar rumah, maka salah satu solusi untuk tetap mendapatkan penghasilan dari rumah, yaitu menggunakan aplikasi bisnis digital. Di sisi lain, aplikasi bisnis digital juga memiliki kekurangan. Sessi ini akan membahas kelebihan dan kekurangan pada platfrom bisnis digitalVTube, Jempol Preneur, dan Goins.

\section{VTube}

Salah satu aplikasi yang sedang populer dan banyak pengguna di era digital ini adalah aplikasi VTube. Berikut ini akan dibahas tentang kelebihan dan kekurangan VTube dari sisi perspektif emik.

Penggunaan aplikasi VTube membuat orang dapat menghasilkan uang tanpa harus keluar rumah dan ini bersesuaian dengan kebijakan pemerintah untuk lebih banyak tinggal di rumah daripada keluar rumah dan beresiko terinfeksi Covid-19. Joe (20 Tahun), misalnya, yang giat dan konsisten dalam penggunaan aplikasi VTube, membuat ia berhasil mendapatkan uang yang cukup banyak dari aplikasi tersebut. Begitupun yang dirasakan oleh Andi (35 Tahun), ia bahkan membeli beberapa VP (view point) untuk ia tabung atau ia simpan dalam aplikasi VTube yang sewaktu- 
waktu akan akan dapat dicairkan sesuai dengan cara yang berlaku di aplikasi VTube. Joe dan Andi sama-sama meyakini bahwa aplikasi VTube bukan aplikasi penipuan karena adanya surat izin dari kominfo dan PSE (penyelenggara sistem elektronik). ${ }^{9} \quad$ Padahal, sebagaimana telah dijelaskan sebelumnya, legalitas VTube masih dipertanyakan.

Berbeda halnya dengan Andjo (22 Tahun), ia merasakan banyak kekurangan dalam menggunakan aplikasi ini. Ketika ia menggunakan aplikasi ini, meskipun ia tidak merekrut anggota atau member karena ia tidak berkemampuan untuk mengundang atau mengajak orang untuk ikut bergabung bersamanya. Akibatnya, penghasilan yang diperolehnya tidak seberapa, sehingga ia merasa hanya banyak menghabiskan waktu ketika menggunakan aplikasi tersebut, dan tidak lagi melanjutkannya. Joe (20 tahun) dan Andi (35 tahun) mengakui bahwa saat ini, VTube sedang tidak bisa digunakan atau dioperasikan seperti biasanya karena sedang dalam masa maintenance. Artinya, pengguna tidak dapat menjalan misi VTube dan dengan demikian tidak mendapatkan penghasilan. Ini semakin mempertegas bahwa ada "sesuatu" yang terjadi dengan VTube dan jika dikaitkan dengan legalitasnya, VTube masih belum mendapatkan izin resmi dari Kominfo dan belum mendapatkan izin sebagai PSE. ${ }^{10}$

\section{Jempol Preneur}

Adapun kelebihan dari aplikasi Jempol Preneur yaitu selain pengguna mendapatkan keuntungan dan penghasilan dari aplikasi ini,

\footnotetext{
${ }^{9} \mathrm{http}: / /$ cirt.bulelengkab.go.id/verifikasi/detail/2273surat-legalitas-dan-perizinan-VTube, diakses tanggal 19 Juni 2021

${ }^{10} \mathrm{https}: / /$ www.tujuwan.com/2021/04/kominfotentang-aplikasi-VTube-terbaru-pt-future-view-techbelum-ada-izin-pse-kominfo.html, diakses tanggal 19 Juni 2021.
}

pengguna juga mendapatkan edukasi tentang bisnis online terlebih bagi pemula. Pemula yang baru ingin merintis usahanya melalui media online, ia akan mendapatkan bantuan dan arahan dari aplikasi ini karena aplikasi telah menyediakan beberapa bacaan terkait bisnis online. Bacaan tersebut seperti cara menjadi dropship atau reseller yang menguntungkan, membuat akun bisnis, dan cara untuk mengetahui akun penipu ketika ingin menjadi dropship atau reseller.

Selain itu, keuntungan yang dirasakan bagi pengguna Jempol Preneur, yaitu tidak lagi susah mencari barang yang bagus, harga terjangkau, dan terpercaya karena semua telah disediakan dalam aplikasi Jempol Preneur. Pengguna hanya memilih jenis jualan apa yang akan dipromosikan dan mengklik tautan yang ada pada aplikasi tersebut, yang secara otomatis akan terhubung langsung pada jenis jualan tersebut. Kemudian, pengguna juga dapat menjual lisensi Jempol Preneur dan akan mendapatkan bonus atau fee karena telah berhasil menjual lisensi Jempol Preneur.

Sedangkan yang dianggap sebagai kekurangan dalam kaitan dengan penggunaan aplikasi Jempol Preneur, yaitu pembayaran untuk menjadi anggota atau member sebesar Rp350.000,- sebagai modal awal membuka usaha. Jika ingin mengembalikan uang tersebut, maka anggota harus mengundang atau merekrut anggota baru untuk bergabung sebagai anggota Jempol Preneur.

\section{Goins}

Kelebihan yang ada pada aplikasi Goins yaitu, keuntungan yang didapatkan cukup banyak dan cepat. Hal inilah yang banyak membuat orang tertarik untuk menggunakan aplikasi Goins. Selain itu, cara kerja yang ada pada Goins cukup mudah, santai dan simple untuk dilakukan, terlebih oleh masyarkat milenial saat ini serta 
mendapatkan hasil yang cukup banyak. Aplikasi ini juga menjadi solusi bagi masyarakat yang belum mendapatkan pekerjaan tetapi ingin mendapatkan penghasilan dengan cara yang mudah dan simple. Namun seiring berjalannya aplikasi Goins, terjadi masalah karena aplikasi Goins tak dapat diakses. Mereka yang sudah menjadi anggota mengalami ketidakpastian dan kemudian berita-berita tentang legalitas aplikasi ini. Ini bukan sekedar menimbulkan pertanyaan tentang legalitas dari aplikasi Goins, tapi justru mempertegas illegalitas aplikasi ini. ${ }^{11}$

Lola (21 tahun), misalnya, ketika ia menggunakan aplikasi Goins awalnya berjalan dengan lancar serta mendapatkan penghasilan sesuai dengan misi yang dijalankan. Setelah menyelesaikan misi tersebut, ia kembali membeli misi tersebut dengan harga sebanyak Rp2.000.000, namun dua minggu kemudia terjadi maintenance pada aplikasi hingga akhirnya tidak lagi bisa digunakan. Adapun kerugian yang didapatkan oleh Lola cukup banyak, yaitu rugi finansial karena uang yang telah ia keluarkan untuk membeli misi tidak kembali serta tidak mendapatkan kejelasan dari pihak Goins.

\section{Kesimpulan dan Rekomendasi}

Pandemi Covid-19 tidak saja menimbulkan ketakutan bagi masyarakat, tapi memengaruhi berbagai aspek kehidupan manusia, termasuk dari sisi perekonomian. Untuk mengurangi penyebaran Covid-19, pemerintah mengeluarkan kebijakan work from home (WFH) dan belajar dari rumah. Ini tidak saja membatasi interaksi antar manusia, tapi kondisi ini juga menyebabkan masyarakt menjadi kreatif dan mencari alternatif untuk mendapatkan penghasilan. Salah satu yang potensil dilakukan

${ }^{11}$ https://insight.kontan.co.id/news/selain-tiktok-cashini-dua-aplikai-ilegal-lain-yang-dilarang-satgasinvestasi, diakses tanggal 20 Juni 2021. adalah bisnis digital, yang tidak saja mudah dan simpel (menggunakan gadget dan jaringan internet), tapi juga dapat dilakukan dimana saja, terutama di rumah karena kebijakan "di rumah aja", sehingga antara mencari penghasilan dan memroteksi diri dari penyebaran virus dengan tinggal di rumah menjadi klop satu sama lain.

Bisnis digital merupakan salah satu jenis usaha dengan pemanfaatan perangkat digital seperti gadget (handphone dan laptop) dan jaringan internet. Setiap bisnis digital yang hadir memiliki platfrom digital dan mempunya cara kerja tersendiri, serta keunggulan yang berbedabeda untuk memikat konsumennya. Ada banyak sekali platform yang bergerak dalam bisnis digital karena dapat dilakukan dengan mudah, dengan cara kerja yang simpel, dengan janji penghasilan yang cukup menggiurkan, dan dapat dilakukan dimana saja. Ini sangat cocok dengan siatuasi pandemi Covid-19 dimana orang dapat berpenghasilan dan tetap tinggal di rumah.

VTube, Jempol Preneur, dan Goins adalah tiga aplikasi yang masing-masing memiliki spesifikasi dan cara kerjanya. Vtube dan Goins merupakan platform digital yang bergerak dalam bidang periklanan, sementara Jempol Preneur adalah aplikasi di bidang online shop. Meskipun ada persamaan di antara ketiganya, yakni masing-masing menghasilkan uang meski satu dengan yang mempunyai variannya sendiri-sendiri.

Penghasilan pengguna VTube tergantung pada capaian penggunanya dengan menonton iklan. Semakin tinggi level yang dijalankan, semakin banyak view point (VP) yang diperoleh; dan semakin banyak VP yang dikumpulkan, semakin banyak penghasilan yang diperoleh. Jika sampai pada level tertentu (rank), penggunanya akan mendapatkan bonus dan ini berkaitan dengan seberapa banyak new member yang berhasil diajak bergabung. 
Dengan cara kerja seperti ini, pengguna VTube akan memerlukan waktu yang relatif lama untuk mendapatkan penghasilan yang besar. Dalam sistem aplikasi aplikasi Jempol Preneur, seseorang harus menjadi anggota untuk dapat menjalankan online shop. Sebagai anggota, mereka tidak saja memilih jenis dan memromosikan barang yang telah disediakan oleh aplikasi, tapi ini juga dapat dijalankan tanpa modal (dropship), atau dengan modal pribadi (reseller). Penghasilan tambahan juga dapat diperoleh melalui penjualan lisensi Jempol Preneur. Semakin banyak lisensi yang terjual, semakin banyak penghasilan yang diperoleh. Sementara Goins yang juga bergerak di bidang periklanan. Penggunanya diharusnya menjalankan misi dengan cara me-like dan menonton video iklan pada aplikasi Instagram. Semakin banyak orang yang diundang bergabung, maka semakin banyak penghasilan yang diperoleh.

Namun, terlepas dari kelebihan yang dimiliki oleh masing-masing aplikasi, masingmasing memiliki kekurangannya. Jika Jempol Preneur telah memiliki legalitas, maka VTube dan Goins sedang under construction, yang menunjukkan bahwa legalitas keduanya belum ada kejelasan dan ini terkait dengan basis daripada bisnis yang dijalankan. Untuk itu, bagi pengguna yang telah terlanjur menjalankan bisnis ini harus siap menanggung resiko yang ada seperti, tidak kembalinya uang sama sekali dan tidak adanya kejelasan dari pihak yang bersangkutan. Aspek lain yang dianggap kekurangan dari Jempol Preneur adalah kewajiban untuk membayar biaya registrasi sementara VTube dan Goins tidak mewajibkan itu.

Bagi prospektif pengguna platform bisnis digital hendaknya berhati-hati dalam memilih aplikasi bisnis digital. Hal pertama yang harus diperhayikan adalah legalitas platform tersebut dan rekam jejaknya, sebelum mencari tahu tentang aturan dan cara kerja dari bisnis tersebut untuk menghindari kerugian yang akan ditimbulkannya. Pemerintah agar semakin gencar mendeteksi platform digital yang tidak jelas karena telah banyak merugikan masyarakat.

\section{Daftar Pustaka}

Aki, M.A. 2015. "Penerapan Sistem Informasi EBusiness Di Indonesia: Prospek dan Tantangan", Jurnal Dakwah Tabligh, 16(2):111-122, http://journal.uinalauddin.ac.id/index.php/tabligh/article Vview/6113, diakses tanggal 23 Mei 2021.

Dwianto, A.R. 2020. “Perjalanan 8 Bulan Pandemi Virus Corona COVID-19 di Indonesia".

https://health.detik.com/beritadetikhealth/d-5240992/perjalanan-8bulan-pandemi-virus-corona-covid-19di-indonesia, diakses tanggal 26 Mei 2020.

Fadly, H. D. dan Sutama. 2020. "Membangun Pemasaran Online dan Digital Branding di Tengah Pandemi Covid-19", Jurnal Ecoment Global, 5(2): 213-221, http://ejournal.uigm.ac.id/index.php/E G/article/view/1042, diakses tanggal 15 Februari 2021.

Febriyantoro, M.T. dan Arisandi, D. 2018. "Pemanfaatan Digital Marketing Bagi Usaha Mikro, Kecil Dan Menengah Pada Era Masyarakat Ekonomi Asean", JMD: Jurnal Manajemen Dewantara, Desember, 1(2):61-76, http://ejournal.stiedewantara.ac.id/ind ex.php/JMD/issue/view/32, diakses tanggal 14 Februari 2021. 
Bisnis Digital: Studi Kasus Penggunaan VTube, Jempol Preneur, dan Goins di Masa Pandemi Covid-19

Hapsoro, B.B.; Palupiningdyah, P.; dan Slamet, A. 2019. "Peran Digital Marketing sebagai Upaya Peningkatan Omset Penjualan Bagi Klaster UMKM di Kota Semarang", Abdimas: Jurnal Pengabdian Kepada Masyarakat, 23(2):117-120, https://journal.unnes.ac.id/nju/index.p hp/abdimas/, diakses tanggal 15 Maret 2021.

Maryati, W. dan Masriani, I. 2019. "Peluang Bisnis Di Era Digital Bagi Generasi Muda Dalam Berwirausaha: Strategi Menguatkan Perekonomian", Jurnal Mebis, $4(2): 53-58$, http://mebis.upnjatim.ac.id/index.php/ mebis/article/view/62/49, diakses tanggal 28 Februari 2021.

Nugraha, A.E.P dan Murniawaty, I. 2018. "Sharia Digital Business: Strategi dan Pengembangan Bisnis Berkelanjutan", Equilibrium: Jurnal Ekonomi Syariah, 6(2):241-252, https://iournal.iainkudus.ac.id/index.ph p/equilibrium, diakses tanggal 11 November 2020.

Priangani, A. 2013. “Memperkuat Manajemen pemasaran Dalam Konteks Persaingan Global". Jurnal Kebangsaan, Juli, 2(4):19,

https://media.neliti.com/media/publica tions/103775-ID-memperkuatmanajemen-pemasaran-dalam-kon.pdf, diakses tanggal 13 Desember 2020.

Ramadhani, Any. 2020. "Tren Pemanfaatn ECommerce di Kalangan UMKM". https://rakyatsulsel.co/2020/08/28/tre n-pemanfaatan-e-commerce-di- kalangan-umkm/, diakses tanggal 26 Mei 2020.

Rosmadi, M.L.N. 2021. "Penerapan Strategi Bisnis di Masa Pandemi Covid-19", Jurnal IKRA-ITH Ekonomika, Maret, 4(1):122-127, https://journals.upiyai.ac.id/index.php/IKRAITHEKONOMIKA/article/view/1064/854, diakses tanggal 20 Mei 2020.

Shalihah, N. Fitriatus. 2020. "Total 1.9 Juta Pekerja di-PHK dan di Rumahkan Akibat Pendemi Virus Corona". https://www.kompas.com/tren/read/20 20/04/19/081000465/total-19-jutapekerja-di-phk-dan-dirumahkan-akibatpandemi-virus-corona?page=all, diakses tanggal 6 Mei 2020.

Suri, D. 2019. “Pemanfaatan Media Komunikasi dan Informasi Dalam Perwujudan Pembangunan Nasional". Jurnal Komunikasi Pembangunan, Juli, 17(2):177-187, https://journal.ipb.ac.id/index.php/jurn alkmp/article/view/26848/17220, diakses tanggal 20 September 2020.

Sutrisni, N.K.E. 2020. "Dampak Pandemi Covid19 Terhadap Bisnis Penjualan Berbasis Online di Bali", Jurnal IImiah Akuntansi dan Bisnis, Desember, 5(2):102-109, https://journal.undiknas.ac.id/index.ph $\mathrm{p} /$ akuntansi/article/view/2826, diakses tanggal 15 September 2020.

Widhianto, W.C. 2002. "E-Business: Teknologi dan Peluang Bisnis di Indonesia", Journal the WinnERS, Maret, 3(1):19-31, https://media.neliti.com/media/publica tions/164833-ID-ebusiness-teknologidan-peluang-bisnis-d.pdf, diakses tanggal 11 Desember 2020. 